CLINICAL STUDY

\title{
Long-term GH treatment improves adult height in children with Noonan syndrome with and without mutations in protein tyrosine phosphatase, non-receptor-type 11
}

\author{
C Noordam, P G M Peer ${ }^{1}$, I Francois ${ }^{2}$, J De Schepper ${ }^{3}$, I van den Burgt ${ }^{4}$ and B J Otten \\ Department of Metabolic and Endocrine Diseases 833, Radboud University Medical Centre, PO Box 9101, 6500 HB Nijmegen, The Netherlands, \\ ${ }^{1}$ Department of Epidemiology and Biostatistics, Radboud University Medical Centre, Nijmegen, The Netherlands, ${ }^{2}$ Department of Paediatric Endocrinology, \\ University of Leuven, Leuven, Belgium, ${ }^{3}$ Department of Paediatric Endocrinology, Free University of Brussels, Brussels, Belgium and ${ }^{4}$ Department of \\ Human Genetics, Radboud University Medical Centre, Nijmegen, The Netherlands
}

(Correspondence should be addressed to C Noordam; Email: c.noordam@cukz.umcn.nl)

\begin{abstract}
Context: Noonan syndrome (NS) is characterized by short stature, typical facial dysmorphology and congenital heart defects. Short-term effect of GH therapy in NS is beneficial, reports on the effect on adult height are scarce.

Objective: To determine the effect of long-term GH therapy in children with NS.

Design: Twenty-nine children with NS were treated with GH until final height was reached.

Setting: Hospital endocrinology departments.

Patients: Children with the clinical diagnosis of NS, with mean age at the start of therapy of 11.0 years, 22 out of 27 tested children had a mutation in the protein tyrosine phosphatase, non-receptor-type 11 gene (PTPN11 gene).

Interventions: $\mathrm{GH}$ was administered subcutaneously at $0.05 \mathrm{mg} / \mathrm{kg}$ per day until growth velocity was $1 \mathrm{~cm} / 6$ months.

Main outcome measure: Linear growth (height) was measured at 3-month intervals in the first year and at 6-month intervals thereafter until final height.

Results: At the start of treatment, median height SDS (H-SDS) was $-2.8(-4.1$ to -1.8$)$ and 0.0 $(-1.4$ to +1.2$)$, based on national and Noonan standards respectively. GH therapy lasted for 3.0-10.3 years (median, 6.4), producing mean gains in H-SDS of $+1.3(+0.2$ to +2.7$)$ and $+1.3(-0.6$ to +2.4 ), based on national and Noonan standards respectively. In 22 children with a mutation in PTPN11 mean gain in H-SDS for National standards was +1.3 , not different from the mean gain in the five children without a mutation in PTPN11+1.3 $(P=0.98)$.

Conclusion: Long-term GH treatment in NS leads to attainment of adult height within the normal range in most patients.
\end{abstract}

European Journal of Endocrinology 159 203-208

\section{Introduction}

Noonan syndrome (NS) is a multiple congenital abnormality syndrome characterized by short stature, a distinctive facial appearance, congenital heart defects (most frequently pulmonary valve stenosis or hypertrophic cardiomyopathy), thoracic deformities, bleeding diathesis and cryptorchidism in male patients (1-3). The incidence of NS is estimated to be between 1:1000 and 1:2500 live births, inheritance is autosomal dominant, although $60 \%$ of cases are sporadic. Tartaglia and colleagues have shown that missense mutations in the protein tyrosine phosphatase, non-receptor-type 11 gene (PTPN11 gene) on the long arm of chromosome 12 encoding the protein tyrosine phosphatase, SHP-2, were the cause of NS in more than $50 \%$ of the cases they examined (4). Recently, mutations in Kirsten retrovirus-associated DNA sequences (K-ras), an effector of activated receptor complexes downstream of SHP-2, have been found in NS and seem to be a rare cause of NS (5). Recently, mutations in Son of Sevenless, homolog 1 (SOS1), v-raf-1 murine leukemia viral oncogene homolog 1 (RAF1) and mitogen-activated and extracellular-signal regulated kinase kinase 1 (MEK1) have been found in clinical cases of NS (6-9). Altogether, mutations in these genes explain $\sim 65 \%$ of clinical cases of NS. Therefore, NS remains a clinical diagnosis.

The median height of subjects with NS is reported to be slightly below -2 SDS for the normal population, with a mean adult height of $162.5 \mathrm{~cm}$ in men and $152.7 \mathrm{~cm}$ in women (10). Over the last two decades, therapeutic trials of growth hormone $(\mathrm{GH})$ have been performed in patients with NS. Short-term results are encouraging, as is the first report on adult height after long-term GH treatment in a prospective study (11-13). With regard to safety of 
long-term GH treatment, we showed that there were no changes in cardiac dimensions and insulin-like growth factor-I (IGF-I) levels remained in the normal range during short-term GH treatment $(14,15)$. Short-term results seem less favourable in children with NS with mutations in PTPN1 1 than without mutations in PTPN11 (16-18). Data on adult height after $\mathrm{GH}$ treatment in relation to the presence or absence of this mutation are not available.

We conducted a partly controlled, multi-centre trial of GH treatment in 37 children with NS. The 4-year results of this study were published in 2001 (11). We now report the adult height data in 29 children with NS in relation to the absence or presence of mutations in PTPN11, SOS1 or ras genes.

\section{Patients and methods}

The original study cohort consisted of 37 children with NS. All the children were referred to one of the participating hospitals (University Hospital Nijmegen; $n=29$ and four Belgian Paediatric Endocrinology Departments; $n=8$ ) for the evaluation of short stature or for the confirmation of the diagnosis of NS. In all cases, the diagnosis of NS was made or confirmed by a clinical geneticist experienced with NS on the basis of previously published criteria (19). Children were included if height SDS (H-SDS) was below -2 and they were prepubertal or in early puberty. Children with hypertrophic cardiomyopathy were excluded. Karyotypes (only performed in girls) were normal. Of these 37 children, nine were lost to follow-up. Table 1 reports relevant details of these nine children; that is, gain in H-SDS over the first 2 years, reasons for and age at withdrawal from the study. Genotypes were not available in these children.

Of the 28 children eligible for final height analysis, 26 reached final height, while 2 were still growing. Three further children with NS, receiving similar treatment in the same hospitals, were included in this analysis. Thus, from a cohort of 40 children with NS, final height can be reported in 29. In the original study protocol reported in 2001, GH treatment was discontinued after 2 years in eight children and restarted after 1 year (11). These children are included in the final height analysis.
Out of 29 children, 27 were tested for mutations in the PTPN11 gene. As part of the cohort reported by Schubbert et al. the five children in which no mutation in PTPN11 was found had the four ras genes (K-ras, H-ras, N-ras and E-ras) sequenced (5). Over the last year, v-raf murine sarcoma viral oncogene homolog B1 (BRAF) and SOS1 genes were also sequenced in these children, for details on the molecular methods, see Zenker et al. 2007 (20).

Growth was measured by experienced observers at 3-month intervals in the first year and at 6-month intervals thereafter, using standard anthropometric techniques. Height was expressed as SDS for age according to national Dutch/Belgian $(21,22)$ and Noonan (10) standards. Pubertal stages, according to Tanner \& Whitehouse (23), were recorded every visit. During the first-year blood counts, IGF-I levels, fasting glucose levels and HbAlc were measured every 3 months, thereafter blood counts, routine biochemistry, IGF-I levels and HbAlc once a year until final height. Echocardiography was performed every 6 months during the first 3 years of treatment and thereafter yearly in 12 children until 5 years of treatment (14). The 21 children with a congenital heart defect also had their regular follow-up at the paediatric cardiology with echocardiography during GH treatment. The results were reported to our hospital.

The GH dosage in all cases was $0.05 \mathrm{mg} / \mathrm{kg}$ per day subcutaneously, 7 days a week in the evening. Dosage was adjusted every 6 months for change in weight. Compliance to $\mathrm{GH}$ treatment was monitored by counting the remaining $\mathrm{GH}$ vials. If the height velocity was below $1 \mathrm{~cm} / 6$ months, GH treatment was discontinued. Final height measurements were taken at least 1 year after the discontinuation of GH treatment. The protocol was approved by the Medical Ethics Committees of the participating hospitals. The study was financially supported by Pfizer (New York, NY, USA).

\section{Data analysis}

Results are expressed as mean, followed by SDS and range, unless indicated otherwise. Differences between variables were tested with a paired t-test or unpaired t-test, when appropriate. Linear regression analysis was

Table 1 Data on patients who discontinued growth hormone treatment.

\begin{tabular}{llll}
\hline Patient number & Response first year & Response second year & Reason for leaving the study \\
\hline 203 & 0.45 & 0.08 & Withdrew voluntarily \\
213 & 0.34 & 0.01 & Psychosocial \\
231 & 0.5 & NA & Withdrew voluntarily \\
103 & 0.22 & 0.00 & Withdrew voluntarily \\
104 & 0.62 & 0.31 & Psychosocial \\
105 & 0.39 & 0.17 & Withdrew voluntarily \\
106 & -0.18 & -0.26 & Died in accident \\
107 & 0.83 & 0.35 & Lost to follow-up \\
108 & 0.62 & 0.59 & Withdrew voluntarily \\
\hline
\end{tabular}

Responses are given as change in height SDS; NA, data not available; age at discontinuation in years. 
performed, with gain in H-SDS for national standards as a dependent variable and age (and bone age) at the start of treatment, gender, parental heights, age at the start of puberty and duration of GH treatment as independent variables (SPSS 14.0, Chicago, IL, USA).

\section{Results}

The clinical characteristics of the 29 children ( 21 boys and 8 girls) are shown in Table 2 . Nine children had a parent with NS (three fathers and six mothers) and twenty cases were sporadic. Mean parental H-SDS was -0.9 $(-2.8$ to +1.3$)$. At the start of treatment, mean age was 11.0 years (median, 11.3 ; range, $5.8-17.5$ years). Mean H-SDS was -2.8 (median, -2.7 ; range, -4.1 to -1.8 ) for national standards and 0.0 (median 0.0; range -1.4 to +1.2 ) for Noonan standards. Mean bone age was 9.0 years (median, 8.9; range, 3.0-14.1 years). Twenty-five children were prepubertal, while four were in early puberty (one girl in Tanner stage B2, three boys in Tanner stage $\mathrm{G} 2$ with testicular volumes of 5,6 and $7 \mathrm{ml}$ ).

In 22 of the 27 tested children, a mutation in the PTPN11 gene was found. In the five children in whom no mutation in PTPN11 was found, sequencing of the four ras genes (K-ras, H-ras, N-ras and E-ras), SOS1 and $B R A F$ genes showed a mutation in SOS1 in one child and a mutation in BRAF in one child. The clinical characteristics of the child with a mutation in BRAF fitted the criteria of NS and not of cardio-faciocutaneous syndrome or Costello syndrome (diagnosed by author IvdB). Thus, in three children, no mutation in one of the genes related to NS was found. Out of 29 children, 21 had a congenital heart defect.

\section{Height}

Median duration of GH treatment was 6.4 years (range, 3.0-10.3 years). The evolution of H-SDS during treatment is shown in Table 3. Expressed as national standards, mean gain in H-SDS was 1.3 (range, -0.2 to $+2.7)$. Expressed as Noonan standards, mean gain in H-SDS was $1.3(-0.6$ to +2.4$)$. Mean adult height in boys was $171.3 \mathrm{~cm}$ (median, 171.6; range, 162.2$182.5 \mathrm{~cm}$ ). Mean adult height in girls was $157.3 \mathrm{~cm}$ (median, 156.4; range 150.8-166.0 cm). Out of the 29 children, 22 reached an adult height in the normal range (H-SDS > $>2$ ). In the 20 sporadic cases, mean $\mathrm{H}-\mathrm{SDS}$ at start minus target height was -2.2 (s.D. 0.9) and mean adult H-SDS was -0.8 (s.D. 0.9).

Table 2 Clinical characteristics of patients with Noonan syndrome who reached final height.

\begin{tabular}{|c|c|c|c|c|c|c|c|}
\hline $\begin{array}{l}\text { Patient } \\
\text { number }\end{array}$ & Sex & Age & $\begin{array}{l}\text { Height-SDS } \\
\text { at start }\end{array}$ & $\begin{array}{l}\text { Pubertal } \\
\text { stage }\end{array}$ & Mutation in PTPN11 & Congenital heart defect & GH therapy (years) \\
\hline 201 & M & 12.0 & -3.1 & Prepubertal & $\begin{array}{l}\operatorname{SOS1}^{+} 1433 \mathrm{C}>\mathrm{G} \\
(\mathrm{P} 478 \mathrm{R})\end{array}$ & $\mathrm{N}$ & 5.5 \\
\hline 202 & $M$ & 13.3 & -3.1 & Prepubertal & $922 \mathrm{~A}>\mathrm{G}(\mathrm{N} 308 \mathrm{D})$ & Pulmonary valve stenosis & 3.3 \\
\hline 204 & $\mathrm{M}$ & 12.6 & -2.7 & Prepubertal & $236 \mathrm{~A}>\mathrm{G}(\mathrm{Q} 79 \mathrm{R})$ & Pulmonary valve stenosis & 5.0 \\
\hline 205 & $\mathrm{M}$ & 14.3 & -3.8 & $5 \mathrm{ml}$ testes & $179 G>C(G 60 A)$ & Pulmonary valve stenosis & 5.0 \\
\hline 206 & M & 8.0 & -3.6 & Prepubertal & $\begin{array}{l}B R A F^{+} 1501 \mathrm{G}>\mathrm{A} \\
\quad(\mathrm{E} 501 \mathrm{~K})\end{array}$ & Pulmonary valve stenosis & 9.9 \\
\hline 207 & $\mathrm{~F}$ & 9.7 & -2.5 & Prepubertal & $184 \mathrm{~T}>\mathrm{G}(\mathrm{Y} 62 \mathrm{~N})$ & Aortic coarctation & 3.9 \\
\hline 208 & $\mathrm{M}$ & 12.3 & -3.5 & Prepubertal & $\mathrm{N}^{*}$ & Pulmonary valve stenosis & 5.0 \\
\hline 209 & $\mathrm{~F}$ & 10.5 & -3.3 & Prepubertal & $922 \mathrm{~A}>\mathrm{G}(\mathrm{N} 308 \mathrm{D})$ & $\mathrm{N}$ & 5.3 \\
\hline 210 & $\mathrm{~F}$ & 6.9 & -4.1 & Prepubertal & $182 A>G(D 61 G)$ & Pulmonary valve stenosis & 9.0 \\
\hline 211 & $\mathrm{M}$ & 6.3 & -2.3 & Prepubertal & $182 A>G(D 61 G)$ & Pulmonary valve stenosis & 9.5 \\
\hline 212 & $\mathrm{M}$ & 10.5 & -3.9 & Prepubertal & $179 \mathrm{G}>\mathrm{C}(\mathrm{G} 60 \mathrm{~A})$ & Pulmonary valve stenosis & 9.5 \\
\hline 214 & $\mathrm{M}$ & 11.5 & -2.5 & Prepubertal & $188 \mathrm{~A}>\mathrm{G}(\mathrm{Y} 63 \mathrm{C})$ & $\mathrm{N}$ & 5.0 \\
\hline 220 & M & 12.6 & -2.1 & $6 \mathrm{ml}$ testes & $922 A>G(N 308 D)$ & $\mathrm{N}$ & 4.0 \\
\hline 221 & $\mathrm{M}$ & 10.4 & -2.2 & Prepubertal & $853 \mathrm{~T}>\mathrm{C}(\mathrm{F} 285 \mathrm{~L})$ & $\mathrm{N}$ & 7.6 \\
\hline 222 & $\mathrm{M}$ & 17.5 & -3.8 & $7 \mathrm{ml}$ testes & $\mathrm{N}^{*}$ & Atrial septal defect & 4.0 \\
\hline 223 & $\mathrm{~F}$ & 11.3 & -3.3 & Prepubertal & $188 \mathrm{~A}>\mathrm{G}(\mathrm{T} 63 \mathrm{C})$ & $\mathrm{N}$ & 6.0 \\
\hline 224 & $\mathrm{M}$ & 12.5 & -3.0 & Prepubertal & $922 A>G(N 308 D)$ & Pulmonary valve stenosis & 7.2 \\
\hline 225 & $\mathrm{~F}$ & 14.7 & -2.8 & Breast 2 & NA & Pulmonary valve stenosis & 3.0 \\
\hline 227 & $\mathrm{M}$ & 8.0 & -2.5 & Prepubertal & $922 A>G(N 308 D)$ & Pulmonary valve stenosis & 10.0 \\
\hline 228 & $\mathrm{~F}$ & 7.5 & -3.5 & Prepubertal & $181 \mathrm{G}>\mathrm{A}(\mathrm{D} 61 \mathrm{~N})$ & Pulmonary valve stenosis & 10.3 \\
\hline 229 & $\mathrm{M}$ & 13.2 & -3.4 & Prepubertal & $1510 \mathrm{~A}>\mathrm{G}(\mathrm{M} 504 \mathrm{~V})$ & $\mathrm{N}$ & 8.1 \\
\hline 230 & $\mathrm{M}$ & 11.3 & -2.1 & Prepubertal & $214 G>T(A 72 S)$ & Pulmonary valve stenosis & 7.5 \\
\hline 233 & $\mathrm{M}$ & 9.3 & -1.8 & Prepubertal & $236 A>G(Q 79 R)$ & $\mathrm{N}$ & 8.4 \\
\hline 235 & M & 9.1 & -2.2 & Prepubertal & $922 A>G(N 308 D)$ & Atrial septal defect & 7.1 \\
\hline 5 & $\mathrm{M}$ & 13.3 & -2.4 & Prepubertal & $\mathrm{N}$ & Pulmonary valve stenosis & 4.7 \\
\hline 2 & $\mathrm{M}$ & 10.9 & -2.5 & Prepubertal & $922 A>G(N 308 D)$ & Pulmonary valve stenosis & 7.5 \\
\hline 372 & $M$ & 12.3 & -1.8 & Prepubertal & NA & Pulmonary valve stenosis & 3.7 \\
\hline 6 & $\mathrm{~F}$ & 11.6 & -1.9 & Prepubertal & $844 \mathrm{~A}>\mathrm{G}(\mathrm{I} 282 \mathrm{~V})$ & Pulmonary valve stenosis & 3.8 \\
\hline 3 & $\mathrm{~F}$ & 5.8 & -2.6 & Prepubertal & $1502 \mathrm{G}>\mathrm{A}(\mathrm{R} 501 \mathrm{~K})$ & Atrial septal defect & 6.9 \\
\hline
\end{tabular}

Height SDS, height standard deviation score; PTPN11, protein tyrosine phosphatase, non-receptor-type $11 ;{ }^{+}$, no mutation in PTPN11, but in gene stated; ${ }^{*}$, in these children the four ras genes and SOS1 were also investigated; NA, data not available; N, no. 
Table 3 Evolution of height SDS (H-SDS) during growth hormone treatment in 29 children.

\begin{tabular}{lrll}
\hline & \multicolumn{1}{l}{ At start } & After 1 year & At final height \\
\hline National standards & $-2.8(0.7,-4.1$ to -1.8$)$ & $-2.3(0.7,-3.8 \text { to }-1.2)^{\star}$ & $-1.5(0.8,-3.0 \text { to }-0.3)^{\star}$ \\
Noonan standards & $0.0(0.8,-1.4$ to +1.2$)$ & $+0.6(0.7,-1.0 \text { to }+2.1)^{*}$ & $+1.2(0.8,-1.1 \text { to }+2.9)^{\star}$ \\
\hline
\end{tabular}

Data are presented as mean (S.D., range). ${ }^{*}$ Significantly different from $\mathrm{H}-\mathrm{SDS}$ at start $(P<0.0001)$

Figure 1 shows graphically the heights at the start of GH treatment and adult height for boys and girls with NS.

Of the 11 children with a gain in H-SDS for Noonan standards below 0.5 in the first year, mean gain in H-SDS for Noonan standards over the course of treatment was 1.2, which was not different from the rest of the group $(+1.3)$.
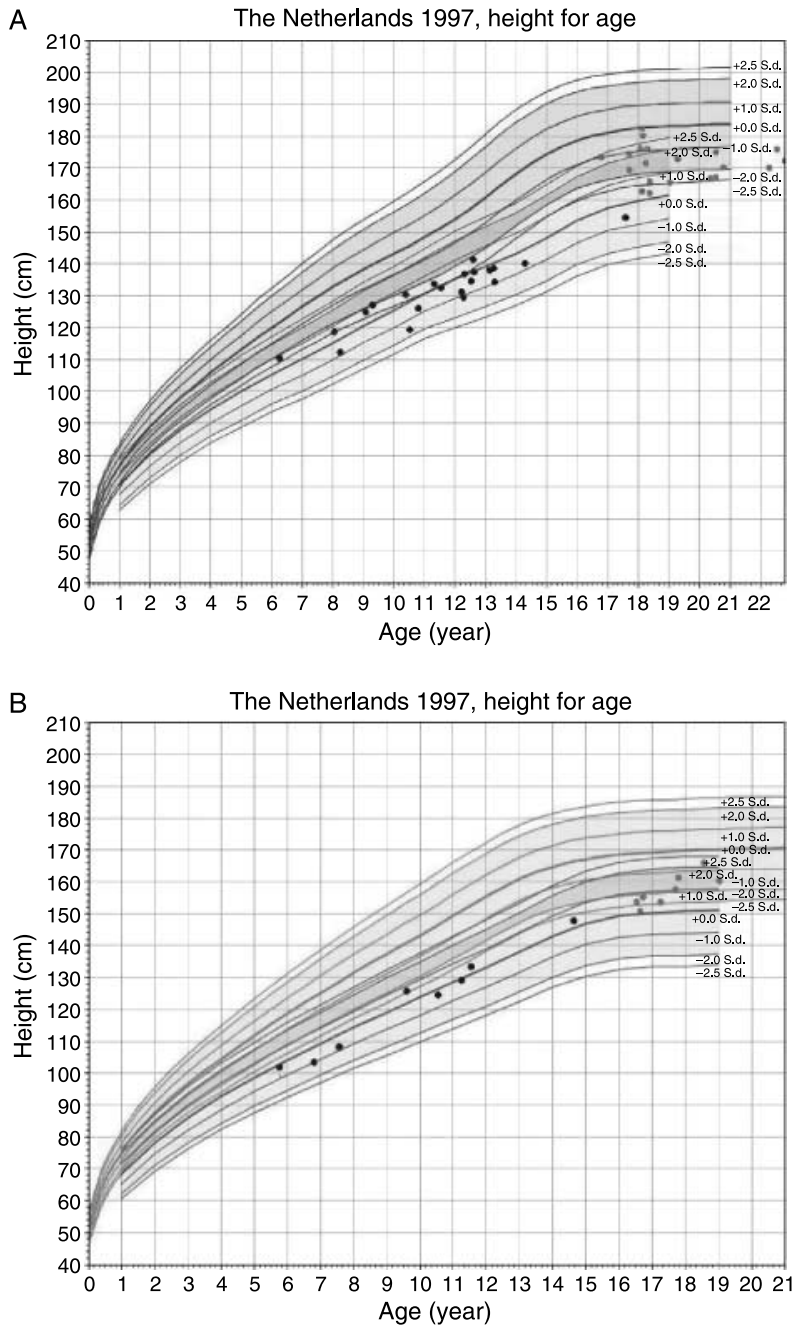

Figure 1 (A) Height of boys with Noonan syndrome at the start of growth hormone treatment (black dots) and at the final height (grey dots). Graph with dark lines: Dutch height standards, with grey lines Noonan height standards. (B) Height of girls with Noonan syndrome at the start of growth hormone treatment (black dots) and at the final height (smaller grey dots). Graph with grey lines: Dutch height standards, with dark lines Noonan height standards.
Median age at the onset of puberty was 13.8 years (range, 11.2-17.5 years) for boys and 13.3 years (range, 12-15.9 years) for girls. Median height at the onset of puberty was $145.1 \mathrm{~cm}$ (mean, 144.2; range, $136.8-156.7 \mathrm{~cm}$ ) in boys and $144.5 \mathrm{~cm}$ (mean, 145.6; range $138.0-153.0 \mathrm{~cm}$ ) in girls. Median increment in height during puberty was $25.6 \mathrm{~cm}$ (range, 19.6$33.7 \mathrm{~cm}$ ) in boys and $13.8 \mathrm{~cm}$ (range, $4.6-22.2 \mathrm{~cm}$ ) in girls.

Linear regression analysis, using total gain in H-SDS for general population standards as a dependent variable, showed that only age at the start of puberty $\left(r^{2}=0.41, P<0.01\right)$ made a statistically significant contribution.

Response to $\mathrm{GH}$ treatment was not significantly different in children with mutations in the PTPN11, compared with children without mutations in PTPN11. Mean gains in H-SDS for national standards were 1.3 $(n=22)$ and $1.3(n=5)$ respectively $(P=0.98,95 \%$ confidence interval of the difference, -1.1 to +1.0 ), while mean gains in H-SDS for Noonan standards were $1.2(n=22)$ and $1.5(n=5)$ respectively $(P=0.39,95 \%$ confidence interval of the difference -1.1 to +0.5 ). Over the first year of $\mathrm{GH}$ treatment, mean gains in H-SDS for national standards were 0.50 in children with mutations in PTPN11 $(n=22)$ and 0.66 in children without mutations in PTPN11 $(n=5)$ respectively $(P=0.41)$, while mean gains in H-SDS for Noonan standards were $0.56(n=22)$ and $0.82(n=5)$ respectively $(P=0.09)$.

Fasting glucose levels were $4.8 \mathrm{mmol} / \mathrm{l}$ (s.D. 0.6) at the start of GH treatment $(n=29), 4.7 \mathrm{mmol} / \mathrm{l}$ (s.D. 0.5) after 1 year $(n=25)$ and $4.9 \mathrm{mmol} / \mathrm{l}$ (s.D. 0.6) at the end of GH treatment $(n=21)$. HbAlc was $5.0 \%$ (s.D. 0.4$)$ at the start of GH treatment $(n=29), 4.9 \%$ (s.D. 0.3) after 1 year $(n=28)$ and $4.8 \%$ (s.D. 0.4) at the end of GH treatment $(n=26)$. Mean IGF-I SDS changed from $0.3(n=29$, range 1.5 to +0.7$)$ to $0.9(n=29$, range -0.8 to +1.8 ) during the first year of GH treatment. Mean IGF-I SDS did not change significantly during the study. Blood counts did not change, in the differential blood count percentage monocytes remained unchanged: $4.7 \%$ at the start of $\mathrm{GH}$ treatment $(n=29), 5.7 \%$ after 1 year $(n=28)$ and $5.1 \%$ at the end of GH treatment $(n=27)$.

Echocardiographic follow-up during the first 5 years of the study in 12 children did not show adverse effects on left ventricular dimensions (14). Regular follow-up in the 21 children with a heart defect did not show changes in ventricular mass. In two boys, there was 
mild progression of pulmonary valve stenosis, in one of them balloon dilatation was necessary. A relation of these events to $\mathrm{GH}$ treatment was considered unlikely.

One girl showed mild progression of pre-existent scoliosis necessitating bracing.

\section{Discussion}

In this paper, we report on a prospective, albeit uncontrolled, study on the effect of GH treatment on adult height in a substantial number of children with NS. In the current study, there was a clear $(+1.3$ s.D. $)$ mean gain in H-SDS, in relation to national or Noonan standards, corresponding to about $9.5 \mathrm{~cm}$ in boys and $9 \mathrm{~cm}$ in girls. When we compare the current data with the 4-year results we reported previously, gain in H-SDS after 4 years was maintained until adult height (11). Our previous concerns about bone age acceleration during the first years of $\mathrm{GH}$ treatment were not confirmed in the current study. We believe, therefore, that the best way to judge the effect of GH treatment in NS is by comparison with Noonan-specific standards, which is superior to assessing gain in H-SDS for bone age. Still, we need an update on Noonan standards from a contemporary cohort with known genotypes.

As in other studies, the wide range in gain in H-SDS is noticeable $(12,24)$. We tried to assess the predictors of a good response to $\mathrm{GH}$ treatment. In linear regression analysis, age at the start of puberty explained most of the variation of the effect of $\mathrm{GH}$ treatment. It would appear that the number of pre-pubertal years spent on GH treatment is very important, although in this study, especially in boys, pubertal growth was comparable with that in normal children. The same finding was made in the study of Osio et al. (13). As GH dosage was the same in these children, no effect of GH dosage was found; however, in line with GH treatment in other conditions, the results of GH treatment in NS from the Pfizer International Growth Study (KIGS), with a lower mean GH dose, showed a slightly smaller increment in adult height (24). In the study of Osio et al. no beneficial effect of a higher $\mathrm{GH}$ dose than the one we used was found. In that study, however, the gain in H-SDS was somewhat better, probably explained by the younger age at the start of $\mathrm{GH}$ treatment (13).

This study is the first to report adult height results after long-term GH treatment in children on whom genetic analysis for NS was performed. We could not confirm previously published observations of a greater gain in H-SDS in the short term in children without PTPN11 mutations, compared with children with mutations in PTPN11 (16-18). We only found a tendency to a better response in children without mutations in PTPN11, especially over the first year of GH treatment. The clear preponderance of children with mutations in PTPN1 1 in this study is a limitation in this respect. Evidence is growing that PTPN11, and thus
SHP-2, mutations cause mild GH resistance by a postreceptor signalling defect (17). Perhaps, the difference in GH response between children with and without PTPN11 mutations is only significant in the short-term and diminishes during long-term GH treatment. This might explain why Binder et al. did not find a difference in height at presentation between children with and without PTPN11 mutations (17).

As the ras and SOS1 mutations have effects downstream of SHP-2 and have no effect on GH receptor signalling, it is reasonable to suggest that the mild GH resistance due to PTPN11, and thus SHP-2, mutations is not present in $45 \%$ of individuals with NS with ras, SOS1 and other, yet to be discovered, germ line mutations that deregulate K-ras signalling $(5,6)$.

The results of our study allow us to give children with NS due to mutations in PTPN11 and their parents an idea of how much height they may gain with $\mathrm{GH}$ treatment. We hope that in a few years we will have the same information for children with NS due to mutations in K-ras, SOS1 and other genes. Whether the benefits of $\mathrm{GH}$ treatment in NS balance the inconvenience of $\mathrm{GH}$ treatment is difficult to say. In our current cohort, we monitored the safety issues related to $\mathrm{GH}$ treatment, i.e. cardiovascular effects, IGF-I levels and effects on carbohydrate metabolism. This was reassuring. Still, our cohort is small and larger series of patients are needed to make definite statements on safety $\mathrm{GH}$ treatment in NS. We would recommend regular echocardiographic follow-up during $\mathrm{GH}$ treatment in children with NS and a heart defect.

This study has its limitations, as the study is not controlled. Therefore, we compared the data with disease-specific growth data and general population standards. The strength of the current study is that we verified the clinical diagnosis in all children, of which we performed mutational analyses in most and that treatment and follow-up were uniform.

In conclusion, we believe that long-term GH treatment in NS results in an increase in adult height. Children with NS due to PTPN11 mutations and their parents can be counselled on the effects of long-term GH treatment.

\section{References}

1 Noonan JA. Hypertelorism with Turner phenotype. A new syndrome with associated congenital heart disease. American Journal of Diseases of Children 1968116 373-380.

2 Allanson JE. Noonan syndrome. Journal of Medical Genetics 1987 24 9-13.

3 Sharland M, Burch M, McKenna WM \& Patton MA. A clinical study of Noonan syndrome. Archives of Disease in Childhood 1992 67 178-183.

4 Tartaglia M, Mehler EL, Goldberg R, Zampino G, Brunner HG, Kremer H, van der Burgt I, Crosby AH, Ion A, Jeffery S, Kalidas K, Patton MA, Kucherlapati RS \& Gelb BD. Mutations in PTPN11, encoding the protein tyrosine phosphatase SHP-2, cause Noonan syndrome. Nature Genetics 200129 465-468. 
5 Schubbert S, Zenker M, Rowe SL, Boll S, Klein C, Bollag G, van der Burgt I, Musante L, Kalscheuer V, Wehner LE, Nguyen H, West B, Zhang KY, Sistermans E, Rauch A, Niemeyer CM, Shannon K \& Kratz CP. Germline KRAS mutations cause Noonan syndrome. Nature Genetics 200638 331-336.

6 Roberts AE, Araki T, Swanson KD, Montgomery KT, Schiripo TA, Joshi VA, Li L, Yassin Y, Tamburino AM, Neel BG \& Kucherlapati RS. Germline gain-of-function mutations in SOS1 cause Noonan syndrome. Nature Genetics 200739 70-74.

7 Razzaque MA, Nishizawa T, Komoike Y, Yagi H, Furutani M, Amo R, Kamisago M, Momma K, Katayama H, Nakagawa M, Fujiwara Y, Matsushima M, Mizuno K, Tokuyama M, Hirota H, Muneuchi J, Higashinakagawa T \& Matsuoka R. Germline gainof-function mutations in RAF1 cause Noonan syndrome. Nature Genetics 200739 1013-1017.

8 Pandit B, Sarkozy A, Pennacchio LA, Carta C, Oishi K, Martinelli S, Pogna EA, Schackwitz W, Ustaszewska A, Landstrom A, Bos JM, Ommen SR, Esposito G, Lepri F, Faul C, Mundel P, López Siguero JP. Tenconi R, Selicorni A, Rossi C, Mazzanti L, Torrente I, Marino B, Digilio MC, Zampino G, Ackerman MJ, Dallapiccola B, Tartaglia M \& Gelb BD. Gain-of-function RAF1 mutations cause Noonan and LEOPARD syndromes with hypertrophic cardiomyopathy. Nature Genetics 200739 1007-1012.

9 Nava C, Hanna N, Michot C, Pereira S, Pouvreau N, Niihori T, Aoki Y, Matsubara Y, Arveiler B, Lacombe D, Pasmant E, Parfait B, Baumann C, Héron D, Sigaudy S, Toutain A, Rio M, Goldenberg A, Leheup B, Verloes A \& Cavé H. Cardio-facio-cutaneous and Noonan syndromes due to mutations in the RAS/MAPK signalling pathway: genotype-phenotype relationships and overlap with Costello syndrome. Journal of Medical Genetics $2007 \mathbf{4 4} 763-771$ (MEK1).

10 Ranke MB, Heidemann P, Knupfer C, Enders H, Schmaltz AA \& Bierich JR. Noonan syndrome: growth and clinical manifestations in 144 cases. European Journal of Pediatrics 1988148 220-227.

11 Noordam C, Van der Burgt I, Sengers RC, Delemarre-van de Waal HA \& Otten BJ. Growth hormone treatment in children with Noonan's syndrome: four year results of a partly controlled trial. Acta Paediatrica 200190 889-894.

12 MacFarlane CE, Brown DC, Johnston LB, Patton MA, Dunger DB, Savage MO, McKenna WJ \& Kelnar CJ. Growth hormone therapy and growth in children with Noonan's syndrome: results of 3 years' follow-up. Journal of Clinical Endocrinology and Metabolism 200186 1953-1956.

13 Osio D, Dahlgren J, Wikland KA \& Westphal O. Improved final height with long-term growth hormone treatment in Noonan syndrome. Acta Paediatrica 200594 1232-1237.

14 Noordam C, Draaisma JM, van den Nieuwenhof J, van der Burgt I, Otten BJ \& Daniels O. Effects of growth hormone treatment on left ventricular dimensions in children with Noonan's syndrome. Hormone Research 200156 110-113.
15 Noordam C, van der Burgt I, Sweep CG, Delemarre-van de Waal HA, Sengers RC \& Otten BJ. Growth hormone (GH) secretion in children with Noonan syndrome: frequently abnormal without consequences for growth or response to $\mathrm{GH}$ treatment. Clinical Endocrinology 200154 53-59.

16 Ferreira LV, Souza SA, Arnhold IJ, Mendonca BB \& Jorge AA. PTPN11 (protein tyrosine phosphatase, nonreceptor type 11) mutations and response to growth hormone therapy in children with Noonan syndrome. Journal of Clinical Endocrinology and Metabolism 200590 5156-5160.

17 Binder G, Neuer K, Ranke MB \& Wittekindt NE. PTPN11 mutations are associated with mild growth hormone resistance in individuals with Noonan syndrome. Journal of Clinical Endocrinology and Metabolism 200590 5377-5381.

18 Limal JM, Parfait B, Cabrol S, Bonnet D, Leheup B, Lyonnet S, Vidaud M \& Le Bouc Y. Noonan syndrome: relationships between genotype, growth, and growth factors. Journal of Clinical Endocrinology and Metabolism 200691 300-306.

19 van der Burgt I, Berends E, Lommen E, van Beersum S, Hamel B \& Mariman E. Clinical and molecular studies in a large Dutch family with Noonan syndrome. American Journal of Medical Genetics 1994 53 187-191.

20 Zenker M, Horn D, Wieczorek D, Allanson J, Pauli S, van der Burgt I, Doerr HG, Gaspar H, Hofbeck M, Gillessen-Kaesbach G, Koch A, Meinecke P, Mundlos S, Nowka A, Rauch A, Reif S, von Schnakenburg C, Seidel H, Wehner LE, Zweier C, Bauhuber S, Matejas V, Kratz CP, Thomas C \& Kutsche K. SOS1 is the second most common Noonan gene but plays no major role in cardiofacio-cutaneous syndrome. Journal of Medical Genetics $2007 \mathbf{4 4}$ 651-656.

21 Fredriks AM, van Buuren S, Burgmeijer RJ, Meulmeester JF, Beuker RJ, Brugman E, Roede MJ, Verloove-Vanhorick SP \& Wit JM. Continuing positive secular growth change in The Netherlands 1955-1997. Pediatric Research 200047 316-323.

22 Hauspie RC, Wachholder A \& Vercauteren M. Reference values of the height and weight growth and growth rate of Belgian boys and girls 3-18 years of age. Archives Françaises de Pédiatrie $1993 \mathbf{5 0}$ 763-769.

23 Tanner JM \& Whitehouse RH. Clinical longitudinal standards for height, weight, height velocity, weight velocity, and stages of puberty. Archives of Disease in Childhood $1976 \mathbf{5 1} 170-179$.

24 Otten BJ, Raaijmakers R, Darendeliler F, Gregory J, Hagenäs L, Hertel T \& Sipalä I. Response to $\mathrm{GH}$ treatment and final height in Noonan syndrome: the KIGS experience. Hormone Research 2004 62164.

Received 27 May 2008

Accepted 28 May 2008 